\title{
DIE INVLOED VAN TEATER OP ADOLESSENTE SE ERVARING VAN SELFAANVAARDING, AANVAARDING VAN ANDER EN VAN HUL OMSTANDIGHEDE
}

\author{
Madeleen Combrink, Herman Strydom, Wilhelm van Deventer
}

\section{INLEIDING}

In hierdie artikel val die fokus op die ervaring van adolessente in Promosa wat aan die teaterproduksie As die skoen jou pas... deelgeneem het (Combrink, 2007). Die tema van die produksie was aanvaarding. Die doel van die artikel is om die persepsieverandering en persoonlike groei met betrekking tot aanvaarding te bepaal wat moontlik tydens die proses van deelname by die betrokke deelnemers plaasgevind het.

\section{PROBLEEMSTELLING}

\section{AGTERGROND}

Promosa is `n gemeenskap wat ongeveer sewe kilometer Noordwes van Potchefstroom geleë is. Die meerderheid inwoners was tydens 'n 2001-sensusopname (StatsSA, 2005:1) bruin, met enkele swart intrekkers. Hierdie gemeenskap bestaan sedert 1969 toe inwoners kragtens die Wet op Groepsgebiede daarheen verskuif is van die destydse Willem Klopperville af (Jansen van Rensburg, 1985:31-32). Uit die geskiedenis en ontstaan van Promosa kan reeds afgelei word dat die gemeenskap se oorsprong gegrond is in verwerping op grond van ras.

Daar is 10094 inwoners in Promosa (Naude, 2004), waarvan die meerderheid adolessente is. Hierdie adolessente word gekonfronteer met 'n verskeidenheid maatskaplike en ekonomiese probleme wat veral die belewing van verwerping tot gevolg het - onder andere verbrokkelde gesinstrukture, afwesige vaderfigure, werkloosheid, armoede en swak skooluitslae (StatsSA, 2005).

\section{PROBLEMATIEK}

Weens die maatskaplike probleme, soos in die agtergrond uiteengesit, is die ouers van adolessente in Promosa dikwels afwesig as gevolg van enkelouerskap, lang werksure, drankmisbruik of swak ouerskapvaardighede. Tydens sy jarelange pastorale werk in Promosa, vind die mede-outeur, Van Deventer, dat adolessente hierdie toedrag van sake interpreteer dat hul ouers dit nie die moeite werd ag om gehalte-tyd met hulle deur te bring nie. "n Gevoel van verwerping word dus ervaar. Die verslag Coming up taller (2006:2) beskryf bogenoemde omstandighede binne "n soortgelyke konteks soos volg:

Mostly, they are "just kids" who were born into economically disadvantaged families and/or resource-poor communities. And being just kids, they long for friendship, approval, protection, security, connectedness and things to do. However, often living in poor communities or stressed families, these youth sometimes grow up with little adult guidance, in fear of physical danger, with few stimulating activities...

Binne hierdie kompleksiteit bevind die adolessent hom/haar boonop in 'n eiesoortige lewensfase, wat vervolgens aandag geniet.

Ten opsigte van hierdie lewensfase sê Vines (2005:1):

During my first year as a middle school counsellor, I learned quickly that feelings, friendships, acceptance, popularity, sexuality, and self-awareness were important to 
adolescents... To make my school counselling program valuable and relevant to students, I realized the need to connect with their souls, and a strong part of their lives was music.

'n Verslag van Coming up taller (2006:1) bevestig dat die kunste waardevolle gereedskap aan kinders en adolessente verskaf wanneer hulle deur hulle onderskeie lewensfases vorder. Adolessensie as lewensfase word gekenmerk deur sekere ontwikkelingstake wat volgens Louw et al. (2004:392) die volgende inhou:

... ontwikkeling van onafhanklikheid van ouers en ander volwassenes; aanvaarding van die self as 'n persoon met waarde en die ontwikkeling van 'n eie identiteit; aanvaarding en aanpassing by sekere groepe.

Binne die lewensfase van die adolessent en ook binne die gemeenskap waarin hy/sy hom/haar bevind, kom drie temas rakende aanvaarding duidelik na vore, naamlik selfaanvaarding, die aanvaarding van ander en ook die aanvaarding van omstandighede. Dryden (1998:9) identifiseer ook hierdie drie temas rakende aanvaarding as selfaanvaarding, aanvaarding van ander en van die wêreld/jou lewensomstandighede.

Aanvaarding word dikwels tydens adolessensie gekweek wanneer die jongmens betrokke is by en deelneem aan aktiwiteite binne sy portuurgroep. In Promosa is daar nie veel geleenthede vir adolessente leerders om konstruktief aan opbouende buitemuurse aktiwiteite deel te neem nie. In die artikel, Partners in programming: Concordia University Inner City Youth Project, meld Ostiguy (1995:1) dat positiewe buitemuurse aktiwiteite die geleentheid aan die jeug bied vir bevredigende betrokkenheid by ander en ook 'n gevoel van aanvaarding, en sekuriteit skep wat tot innerlike gesondheid lei. Die Concordia Inner City Youth Project sluit drama en dans in.

In 'n verslag van Coming up taller (2006:1) word hierdie standpunt rakende deelname verder bevestig. Hulle stel dat georganiseerde aktiwiteite vir jongmense riskante gedrag by adolessente kan voorkom. Studente wat in 'n orkes speel, in 'n koor of sing of aan skooldramas deelneem, is byvoorbeeld beduidend minder geneig om die skool vroeg te verlaat, gearresteer te word, en dwelms of drank te misbruik as dié wat nie daaraan deelneem nie. Dieselfde studie wys ook daarop dat deesdae se mees weerlose jeug ongelukkig minder tyd aan aktiwiteite soos dié bestee en dat hulle dus ook nie die voordele daarvan kan geniet nie.

In hierdie navorsing is daar spesifiek gefokus op deelname aan 'n teaterproduksie. Binne die raamwerk van maatskaplike werk sal hierdie teaterproduksie geklassifiseer word as 'n vorm van gemeenskapsontwikkeling, en meer spesifiek gemeenskapsopvoeding. Weyers (2001:191) noem dit Teater vir Ontwikkeling. Augusto Boal (soos aangehaal deur Combrink, 2002:2) sluit hierby aan deur te sê: "Theatre is a form of knowledge; it should and can also be a means of transforming society." Artslynx International Arts resources (2004:1) bevestig hierdie stelling:

The arts can be a powerful force for healing, but they can also be a force for building communities; for nurturing human creativity and well-being, and for empowering individuals and helping them to realize their full positive potential.

Aangesien daar in Promosa 'n leemte bestaan ten opsigte van georganiseerde aktiwiteite waaraan adolessente kan deelneem, is die projek Karos \& Kambro in 2000 gestig. Die Jeugontwikkelingsprojek bied aan adolessente die geleentheid om hulle dans- en dramavaardighede in die vorm van teaterproduksies te ontwikkel en ten toon te stel. Volgens Combrink (2002:3) is Karos \& Kambro: 
... a project in which theatre, as powerful medium, is employed as a holistic and potential development process in the lives of marginalized children - who most of the time are illprepared for the battle of life and the art of living... Through Karos \& Kambro, upliftment and empowerment of children and communities take place by means of investing in the real potential of some hidden, silent, wounded youth of this country.

Karos \& Kambro se ontwikkelingsprogram beslaan hoofsaaklik drie vlakke, naamlik:

- twee kampe per jaar waartydens daar op leierskap en lewensvaardighede gefokus word,

- $\quad$ weeklikse werkswinkels waartydens daar in die adolessente se potensiaal en vaardighede op die gebied van die uitvoerende kunste (veral dans en drama) belê word, en

- twee teaterproduksies per jaar wat die uitkoms en integrering is van wat aangaande dans- en dramavaardighede asook lewensvaardighede geleer is.

Die navorsing het op aanvaarding as tema van die teaterproduksie gefokus - ' $\mathrm{n}$ tema wat reeds vooraf tydens 'n kamp wat van 2-4 Maart 2007 plaasgevind het, behandel is. Tydens die weeklikse werkswinkels voor en na die kamp is aandag ook geskenk aan hierdie lewensvaardigheid, naamlik aanvaarding. Die vaardigheidsontwikkeling wat by die kamp en tydens die weeklikse werkswinkels plaasgevind het, is verder deur middel van die teaterproduksie As die skoen jou pas .... belig. Die teks van die produksie is in opdrag van Karos \& Kambro geskryf om die problematiek rakende aanvaarding onder die loep te neem. Die teaterproduksie was derhalwe die eindresultaat van 'n omvattende proses. Volgens Combrink (2002:3) is 'n doelstelling van Karos \& Kambro:

...to determine the power of theatre, arts and positive life skills as a holistic and potential development process in the lives of marginalized children. We do not use children in the first place to produce well-coached, professional productions. Instead, we use drama and music as a transformation process, to expand their awareness, to act out alternative possibilities in their lives.

\section{NAVORSINGSVRAE}

Uit die problematiek wat hierbo uiteengesit is, is die volgende primêre navorsingsvraag ondersoek: Watter invloed het deelname aan 'n teaterproduksie op adolessente in Promosa se persepsie van selfaanvaarding, aanvaarding van ander en van hul omstandighede en op hulle persoonlike groei in hierdie verband gehad?

Sekondêre vrae wat hieruit voortgevloei het, is:

- Watter persepsieverandering en persoonlike groei het onder adolessente in Promosa plaasgevind met betrekking tot die aanvaarding van ander weens hul deelname aan 'n teaterproduksie?

- Watter persepsieverandering en persoonlike groei het onder adolessente in Promosa plaasgevind met betrekking tot selfaanvaarding weens hul deelname aan 'n teaterproduksie?

- $\quad$ watter persepsieverandering en persoonlike groei het onder adolessente in Promosa plaasgevind met betrekking tot die aanvaarding van omstandighede weens hul deelname aan 'n teaterproduksie? 


\section{DOELSTELLING EN DOELWITTE}

Die algemene doelstelling was om deur middel van kwalitatiewe navorsing die invloed te bepaal wat deelname aan 'n teaterproduksie op adolessente in Promosa se persepsie van en persoonlike groei met betrekking tot selfaanvaarding, aanvaarding van ander en van hul omstandighede gehad het.

\section{Die spesifieke doelwitte was}

- Om die persepsieverandering en persoonlike groei onder adolessente in Promosa te bepaal met betrekking tot selfaanvaarding weens hul deelname aan 'n teaterproduksie.

- Om die persepsieverandering en persoonlike groei onder adolessente in Promosa te bepaal met betrekking tot die aanvaarding van ander weens hul deelname aan 'n teaterproduksie.

- Om die persepsieverandering en persoonlike groei onder adolessente in Promosa te bepaal met betrekking tot die aanvaarding van omstandighede weens hul deelname aan 'n teaterproduksie.

\section{METODOLOGIE}

\section{NAVORSINGSONTWERP}

Kwalitatiewe navorsing is aangewend deur reeds voor die aanvang van die teaterproduksie van die narratiewe benadering gebruik te maak. 'n Vraag is gestel oor die deelnemers se verstaan van die begrip aanvaarding waarna hulle 'n toeligtende verhaal daaroor moes skryf. Na afloop van die teaterproduksie is fokusgroepgesprekke gehou om bykomstige data in te samel.

Die kwalitatiewe navorsingsontwerp wat gebruik is, is 'n gevallestudie, aangesien daar 'n indieptestudie met die navorsingsdeelnemers gedoen is. Fouché (2005:272) meld dat "the case being studied may refer to a process, activity, event, programme or individual or multiple individuals." In hierdie geval is daar dus op 'n gebeurtenis gefokus, naamlik 'n teaterproduksie. In hierdie geval val die klem op die geval/gebeurtenis asook die vraagstuk wat daardeur aangeroer word, naamlik aanvaarding. Die tipe gevallestudie waarvan gebruik gemaak is, is 'n instrumentele gevallestudie.

\section{NAVORSINGSDEELNEMERS}

Die Karos \& Kambro-lede in Promosa was die navorsingsdeelnemers. Dit is dieselfde groep adolessente wat aan die teaterproduksie As die skoen jou pas deelgeneem het, maar wat ook 'n jaar lank deel uitgemaak het van Karos \& Kambro-kampe en weeklikse byeenkomste ... Daar was 27 deelnemers, van wie 13 vroulik en 14 manlik is met 'n ouderdomsverspreiding wat wissel tussen 13 en 20 jaar.

\section{NAVORSINGSPROSES}

In die kwalitatiewe ondersoek is die navorsingsdeelnemers voor die aanvang van die teaterproduksie versoek om die vraag "Wat dink jy is aanvaarding?" skriftelik te beantwoord en op daardie antwoord uit te brei deur die narratiewe benadering te gebruik ('n verhaal te skryf). Volgens Lieblich en Josselson (1997:15) het sekere navorsers tot die gevolgtrekking gekom dat die narratiewe benadering die betekenis van persoonlike ervaringe na vore bring. Daar is na afloop van die teaterproduksie indiepteonderhoude gevoer deur van fokusgroepe gebruik te maak.

Tematiese data-analisering het plaasgevind deur die volgende stappe te volg:

- 'n Oorsig van al die ingesamelde data is verkry. 
- Kernkonsepte en -frases in die beskrywings van aanvaarding, die verhale en die fokusgroeponderhoude is afsonderlik geïdentifiseer om sodoende temas te vorm.

- Die ooreenstemmende, teenstrydige en losstaande temas is gegroepeer.

- Hierdie temas is verdeel in drie fokusareas, naamlik aanvaarding van ander, selfaanvaarding en aanvaarding van omstandighede.

- Die temas wat afsonderlik by die verskillende data-insamelingsmetodes geïdentifiseer is, is uiteindelik onder die drie genoemde fokusareas geïntegreer.

- Op hierdie wyse is triangulasie ook verseker.

\section{ETIESE ASPEKTE}

Etiese aspekte wat tydens hierdie ondersoek ter sprake was, was hoofsaaklik ingeligte toestemming, konfidensialiteit en samewerking met bydraers (Strydom, 2005:57-67). Ingeligte toestemming is van die navorsingsdeelnemers verkry deurdat deeglike inligting vooraf gegee is rakende die doel en aard van die navorsing en die navorsingsdeelnemers het skriftelik ingestem dat hulle wel bereid is om aan die navorsingsproses deel te neem.

Wat konfidensialiteit en anonimiteit betref, is die proefpersone vooraf daarvan verseker dat die inligting as vertroulik hanteer sal word en dat slegs pseudoname in die navorsingsverslag aangewend sal word.

Ten opsigte van samewerking met die bydraers het die navorser toestemming van die bestuur van Karos \& Kambro verkry om met die navorsing voort te gaan met voorbehoud dat daar by die organisasie se navorsingsbeleid gehou word. Daar is ook vooraf goedkeuring van die Vakgroep Maatskaplike Werk by die Noordwes-Universiteit, Potchefstroomkampus, verkry vir die navorsingsvoorstel wat ingedien is.

\section{BEVINDINGE}

Die begrip aanvaarding word in hierdie artikel as 'n holistiese en geïntegreerde konsep gehandhaaf. Alhoewel dit dus nie op 'n waterdigte wyse onderverdeel kan word nie, is daar vir doeleindes van analise en die formulering van bevindinge gebruik gemaak van 'n drievoudige onderskeiding, naamlik:

- Aanvaarding van ander

- Aanvaarding van die self

- Aanvaarding van omstandighede

Hierdie drieërlei onderskeiding sal vervolgens uit die geskrewe en verbale data in drie kategorieë aan die orde gestel word:

- Die deelnemers se eie verstaan van die begrip aanvaarding.

- Hul omskrywing van die begrip in narratiewe vorm.

- Interpretasie van die begrip binne die fokusgroepe.

Ten slotte sal bogenoemde onderskeidings en kategorieë deur middel van 'n opsommende bespreking tot ' $n$ geheel geïntegreer word. Enkele bevindinge rakende die navorsingsproses sal ook aandag geniet, waarna aanbevelings gemaak sal word.

\section{DEELNEMERS SE OMSKRYWING VAN DIE BEGRIP AANVAARDING}

Die Handboek van die Afrikaanse Taal (HAT, 1994:11) definieer aanvaarding as "[i]n besit neem; aanneem; deurstaan; die laste van die lewe aanvaar." Hierteenoor staan die begrip 
verwerping wat dikwels voorgekom het of deur die deelnemers geïnsinueer is. Hierdie begrip word deur die HAT (1994:1203) gedefinieer as: "Wegstoot; afwys; nie goedkeur, aanvaar nie; afkeur." Op die vraag rakende die deelnemers se verstaan van die begrip aanvaarding voor die aanvang van die teaterproduksie het die volgende uit hul geskrewe reaksies uitgekristalliseer:

\section{Aanvaarding van ander}

Aanvaarding van die ander is op verskillende wyses deur die deelnemers omskryf. Temas wat prominent na vore gekom het, dui op die aanvaarding van ander op grond van hul menswees ten spyte van hul handelinge (al sou dit hulleself ook al in die verlede benadeel het), kultuur, taal, 'n mens se eie gevoelens, die menings van ander, ouderdom, verwantskap en ekonomiese stand. In 'n verslag van Coming up taller (2006:2) word ekonomiese stand as 'n gegewe beskryf: "...they are "just kids" who were born into economically disadvantaged families and/or resource-poor communities." Die adolessente kan dus nie kies of hulle arm of ryk is nie, maar ekonomiese stand word tog in verband gebring met aanvaarding deurdat dit as voorwaarde vir aanvaarding dien of as rede vir die verwerping van ander. Wat ook beklemtoon is, is onvoorwaardelike en nie-veroordelende aanvaarding van die ander - nie op grond van uiterlikhede nie, maar op grond daarvan dat die persoon waag om die ander te aanvaar soos die persoon self aanvaar word en asof hulle eie familie is.

\section{Selfaanvaarding}

Selfaanvaarding word deur die deelnemers omskryf as dat iemand wat homself/haarself as persoon aanvaar en sy/haar eie optrede/handelinge aanvaar. Selfaanvaarding word ook in verband gebring met 'n suksesvolle toekoms. Verder word daar gemeld dat selfaanvaarding plaasvind ten spyte van verwerping deur ander. Aanhalings ter illustrasie hiervan is:

- "Jou familie aanvaar jou en jou vriende en jy moet vir jou ook aanvaar."

- "Aanvaarding is iets wat jy moet doen om iets te bereik wat jy wil, om te wees wat jy is, ten spyte van wat mense van jou sal sê of dink."

\section{Aanvaarding van omstandighede}

Die deelnemers het die aanvaarding van omstandighede beskryf as die aanvaarding van wat 'n persoon ontvang en om waardering te hê vir besittings en omstandighede. Aanvaarding van omstandighede is ook in verband gebring met die verlede en die onveranderlike. Ter stawing, enkele aantekeninge:

- "Acceptance is all about appreciating what you have and then appreciating everything around you.

- "To accept the things you can't change."

\section{OMSKRYWING VAN DIE BEGRIP AANVAARDING IN NARRATIEWE VORM}

Direk nadat die deelnemers hulle eie geskrewe omskrywing van die begrip aanvaarding gegee het, is hulle versoek om dit aan die hand van 'n verhaal toe te lig om sodoende die betrokke begrip in narratiewe vorm uit te beeld. Die meerderheid verhale het dieselfde verloop gehad, naamlik dat daar aanvanklik verwerping was. Daarna het insigontwikkeling plaasgevind en uiteindelik het aanvaarding ingetree. Aangesien verwerping en aanvaarding lynreg teenoor mekaar staan, sal verwerping as onderwerp dikwels in die aanhalings voorkom:

- “...Dirk het toe besluit om hom te ontrek van sy vriende af...Dirk het toe 'n tydskrif gelees...oor aanvaarding... gedink wat hy aan sy vriende doen is nie reg nie... hy het toe besluit om sy vriende te aanvaar vir wie hulle is en nie vir wat hulle doen nie." 
- "No one wanted to be friends with that boy because of his skin colour...girl telling the children: that is a person like you and me... so many children became friends with this boy."

Temas voortvloeiend uit die narratiewe ondersoek word vervolgens uitgelig. Die verhale wat geskryf is, het hoofsaaklik gefokus op aanvaarding van ander. Daar was slegs twee verhale waarin selfaanvaarding beklemtoon is. Omstandighede is slegs as rede vir verwerping aangedui en het na vore gekom in stories waar die aanvaarding of verwerping van ander die hooffokus was.

\section{Aanvaarding van ander}

In die meeste verhale is daar na "ander" verwys in die konteks van vriende of skoolkinders, selfs sportspanne. Hieruit is dit duidelik dat die portuurgroep van die adolessent ' $\mathrm{n}$ primêre rol in hierdie lewensfase vervul. Louw et al. (2004:392) bevestig die onafhanklikheidwording en inskakeling by die portuurgroep as ontwikkelingstake tydens adolessensie: “...ontwikkeling van onafhanklikheid van ouers...aanvaarding en aanpassing by sekere groepe."

Temas wat duidelik na vore gekom het, was die aanvaarding van ander ten spyte van fisiese gestremdheid, ras, negatiewe optrede/houdings, onvermoë, talente, leergierigheid, intellektuele vermoëns en geloof. 'n Subtema in een van die verhale waarin daar verwys is na verwerping op grond van fisiese gestremdheid was ook mense wat nie omgee nie. Die Oxford Dictionary of English (2003:1485) definieer verwerping soos volg: "To dismiss as inadequate, unacceptable or faulty; fail to show due affection or concern for someone."

Daar is ook gemeld dat ander aanvaar moet word op grond van innerlike en uiterlike skoonheid. Nog 'n tema wat na vore gekom het, was die aanvaarding van ander omdat aanvaarding deur ander ervaar word. Aanvaarding is verder in verband gebring met liefde, hulp, geluk en vriendskap. Vines (2005:1) meen ook dat vriendskap onder adolessente 'n sentrale tema is: "I quickly learned that feelings, friendship, acceptance...were important to adolescents." Aanvaarding hou ook verband met 'n gevoel van behoort aan, en met respek, waardering en 'n tweede kans. Daar is gemeld dat aanvaarding verband hou daarmee om in ander te glo. Die Oxford Dictionary of English (2003:9) definieer aanvaarding as: "To believe or come to recognize as valid or correct." Laastens is aanvaarding van ander ook in verband gebring met diere.

\section{Selfaanvaarding}

Selfaanvaarding word beskryf as die aanvaarding van die self ten spyte van fisiese gestremdheid en ander se menings of opmerkings. Dit word ook in verband gebring met sukses.

- “...'n groot massiewe boggel op jou rug... sal eendag vir myself sê: "ek is goed in wat ek doen en ek sal nie dat wat ander vir my sê of dink my onder kry nie..."

- "She did not worry about how the children looked at her or how they spoke behind her back or even how they made fun of her."

- “...ek sal speel en ons span laat wen..."

\section{Aanvaarding van omstandighede OF Verwerping op grond van omstandighede}

Omstandighede hou verband met armoede of finansiële status en sukses. Daar is ook klem gelê op aanvaarding van die verlede, verlies en die onveranderlike.

- “...swart man wat ryk was... iets van sy lewe gemaak... Michael wil nie vir Thabo aanvaar vir die beter persoon wat hy is nie." 
- "...her parents didn't like him, they say that he is poor..."

- "...did not have a lot of money...did not have money to buy school clothes...did not have anything to eat...no one wanted to be friends with her."

- “...she passed away... at the end accepted that his wife passed away...He taught his son that he must accept the things he can't change, 'cause life goes on'."

\section{INTERPRETASIE VAN DIE BEGRIP AANVAARDING BINNE DIE FOKUSGROEPE}

$\mathrm{Na}$ afloop van die teaterproduksie is die volgende vraag binne die fokusgroepe aan die deelnemers gestel: "Wat het julle geleer tydens die produksie, veral oor aanvaarding?". Uit die reaksie op hierdie vraag het dit duidelik geword dat die deelnemers se persepsies oor aanvaarding verbreed het en dat daar bepaald persoonlike groei ten opsigte van aanvaarding plaasgevind het. Groei het nie alleen by die deelnemers plaasgevind nie, maar ook by die gemeenskapslede wat deel uitgemaak het van die gehoor. Dit blyk duidelik uit die volgende frases en aanhalings:

\section{Groei / verandering by die deelnemers}

- “Ons kyk die lewe nou regtig met'n ander oog. Ek sê laas vir die mense by my huis, dis vir my net gevaarlik-kwaai-lekker om dinge in so ander way te kyk."

- "The theme the past few months was acceptance. At first, we only saw it as a word: Acceptance is just acceptance, but $K \& \mathrm{~K}$ it really helps us to see that it's much more than just a word. There are different kinds of acceptance that we have experienced."

\section{Groei / verandering in die gemeenskap}

- "I think the production has touched people in different ways...It must have touched a lot of people in the community. So this production also delivered to the community, not only to us."

Artslynx International Arts resources (2004:1) bevestig dit: "The arts can be a powerful force for healing, but it can also be a force for building communities." Augusto Boal (soos aangehaal deur Combrink (2002:2)) sluit hierby aan: "Theatre is a form of knowledge: it should and can also be a means of transforming society."

Soos reeds gemeld, is die drie temas oor aanvaarding sterk vervleg en hou dit verband met mekaar. Tydens die fokusgroepe het dit baie duidelik na vore gekom dat hierdie temas nie waterdig van mekaar geskei kan word nie, en dat die een vorm van aanvaarding bepaald 'n invloed op die volgende vorm daarvan uitoefen. In hierdie afdeling is weereens onderskeid getref tussen die drie temas. Dit word vervolgens bespreek soos dit uit die fokusgroepe na vore gekom het.

\section{Aanvaarding van/deur ander}

Die deelnemers het aanvaarding van/deur ander uit verskillende oogpunte bespreek. Temas wat na vore gekom het, is die aanvaarding van ander ten spyte van ras en finansiële status en op grond van menswees (wie iemand is). Aanvaarding is deurentyd in 'n Christelike konteks gebruik waartydens daar na die Bybel of na God verwys is. Aanvaarding is ook in verband gebring met respek, liefde, sukses, vriendskap en 'n persoon se vermoë om te kan gee. Jaloesie is as teenoorgestelde van aanvaarding voorgehou. Aanvaarding van ander en selfaanvaarding word as voorwaardes gestel om aanvaarding deur ander te beleef. Veroordeling op grond van die uiterlike het ook aan bod gekom. 
Sub-temas van aanvaarding van/deur ander wat voorgehou is, is aanvaarding/verwerping op grond van die uiterlike; familielede wat na die teaterproduksie kom kyk het en 'n aanduiding van aanvaarding vir die deelnemers was die mate waarin ander (nie-deelnemers) se persepsie ten opsigte van die deelnemers self verander het; die produksiespan se aanvaarding van die deelnemers en die deelnemers se aanvaarding wat mekaar onderling.

Wat aanvaarding deur die produksiespan betref, het dié gepoog om in alle opsigte aanvaarding teenoor die deelnemers te toon. So byvoorbeeld is die teks deur die regisseur aangepas sodat die taalgebruik eie aan die gemeenskap kon bly. Die choreograaf het deurentyd insette van die deelnemers gevra en by die danse ingewerk en sodoende is hulle dansstyl en insette as aanvaarbaar beskryf. Die produksiespan het deurentyd gepoog om die volgende definisie van aanvaarding, soos beskryf in die Nuwe Woordeboek vir Maatskaplike Werk (1996:1), teenoor die deelnemers uit te leef: "Principle in Social Work whereby the attitude and actions of the social worker demonstrate that he respects the client's dignity as a human being, that he understands his behavior and feelings and that he does not judge him."

\section{Selfaanvaarding}

Wanneer iemand hom/haar met ander vergelyk en deurgaans begeer om soos die ander te wees, blyk dit dat hy/sy homself/haarself nie aanvaar nie. Hierdie tema het deurlopend tydens die fokusgroepe na vore gekom. Die deelnemers was ook die mening toegedaan dat selfaanvaarding, ten spyte van probleme, 'n verantwoordelikheidsin kan meebring. Ander temas wat hierby aansluit en ook deur die deelnemers aangeraak is, was selfaanvaarding ten spyte van ander se menings en die feit dat selfaanvaarding verband hou met selfvertroue. Die volgende aanhalings ondersteun die bogenoemde temas:

- "Al het ek partykeer baie keer gewens ek kon in iemand anderster se skoene wees, want my lewe was altyd nie lekker nie, maar daardie aand het ek besef om in jou eie skoene te wees, is beter as om in ander iemand se skoene te wees."

- "In daai storie, soos Jo gesê het, al sou hulle dit nie admit nie, daar was ook mense wat soos ander mense wou wees. En daai storie het gemaak dat ek dink, nee, dis hoe jy is. As die Here jou mos soos daai persoon wou gemaak het, dan sou jy mos so geraak het."

- “...ek het eintlik geaanvaar toe ek nou nog gedink het om soos Rabecca te wees, ek't altyd gedink sy lyk mooi van buite af, maar toe ek haar huisomstandighede sien van binne, toe wil ek glad en geheel nie soos sy wees nie. Want sy's mooi buite, maar in die huis was dit nie te cool gewees nie. So ek het vir my aanvaar vir wie ek is. Ek was die slimste kind in die klas in, al het ek lelik aangetrek en wat alles gedoen."

- "Mense create 'n karakter van homself. Hoe dit ook gecreate word, is as iemand anders 'n persoon kritiseer en die persoon gaan ook terug om te gaan kyk hoe lyk die persoon in die spieël in, dan's die persoon se gedagte klaar besoedel, dan gaan die persoon dink om te sê: "miskien is dit regtig so, want as die straatmense so dink, dan moet ek maar 'n verandering doen." Maar as my liggaam sê dit is fine, dan is dit fine."

- "Ek het geleer om iets van om myself te aanvaar - wie ek is en hoe ek lyk. En wat ander mense van my sê of wat ander mense nie van my like nie...maak nie vir my saak nie, want die Here het my gemaak soos ek hier is vandag en daar is nie 'n probleem weer met my nie. Altyd as ek in die spieël in gekyk het dan het ek gesê: "Uhh, moet ek alweer in jou gesig in kyk?" En nou, is maar net wie ek is. Ek kan elke dag opstaan en in my eie gesig inkyk en sê ja, jy is 'n mooi meisie en so..." 


\section{Aanvaarding van omstandighede}

In die storielyn van die teaterproduksie het die hoofkarakters elkeen gewens dat hy/sy in iemand anders se omstandighede kon verkeer, omdat die aanname gemaak is dat dit beter sou wees. Die deelnemers se insig en persoonlike ervarings/groei ten opsigte hiervan word duidelik uit die onderstaande aanhalings. Aspekte van die aanvaarding van omstandighede wat ook tydens die fokusgroepe onder oë gesien is, is dat omstandighede aanvaar kan word ten spyte van probleme (byvoorbeeld alkoholisme, verwerping deur ' $\mathrm{n}$ biologiese ouer of 'n stiefouer). Ander mense in ander omstandighede ervaar óók probleme, en empatie word bewerkstellig wanneer 'n persoon hom in 'n ander een se situasie/omstandighede kan indink (of deur middel van rollespel wat uitdruklik deur die teaterproduksie plaasgevind het). Die aanvaarding van besittings en van die dood van 'n geliefde in die verlede is ook verreken.

- "...maar toe ek haar huisomstandighede sien van binne, toe wil ek glad en geheel nie soos sy wees nie. Want sy's mooi buite, maar in die huis was dit nie te cool gewees nie..."

- "En by die huis - daar is probleme, al wens jy jy kon in iemand anders se skoene gewas het, daai ou het miskien ook probleme en jy weet nie, is dit miskien nou seerder as joune nie. Maar ek wil net sê ek het gesien daar by daai storie, dis nie net ek wat probleme het nie, ander het ook probleme, al lyk dit nie so nie. Hulle steek dit net weg."

- “...'n mens soek nie altyd jou eie lewe nie, want die omstandighede daar waar jy bly is nie soos jy dit wil hê nie. Okey, ek het nou my ma verloor toe's ek vyf jaar. Maar toe het my pa, soos in my oom, my loving oom, ek vat hom soos my pa, het hy my grootgemaak...Maar ek verlang regtig na my ma."

- "What I mostly have learned...is that most of the times we actually misinterpret things...there's more to life than what we actually think and...see. So don't think that one has a wonderful life - you just see him walking past the street looking beautiful, and you think his life is so perfect, he needs nothing and all. Like my role, Joe, he wanted to be Sonny, he thought Sonny's life was perfect and everything, but when he really got in Sonny's shoes, literally and figuratively, he really came to the experience that there's really more to life than what we see. He misinterpreted the situation."

- “...ek moet eintlik die goete aanvaar wat ek het. Ek moet bly wees, want daar's mense wat nie het nie, wat minder as my goete het, so ek moet net aanvaar wat ek het."

\section{INTEGRASIE VAN BEVINDINGE}

Uit die kwalitatiewe data wat voor die begin van die teaterproduksie ingesamel is, is dit duidelik dat die deelnemers reeds vooraf'n goeie begrip van die konsep aanvaarding gehad het. Dit kan veral toegeskryf word aan die Karos \& Kambro-kamp wat spesifiek op hierdie tema gefokus het. Daar het steeds bepaald persepsieverandering en groei plaasgevind as gevolg van die teaterproduksie. 'n Verslag van Coming up taller (2006:1) bevestig die feit dat ontwikkeling deur die kunste gefasiliteer kan word: "Arts and the humanities programs are particularly potent in promoting youth development." Vanuit die fokusgroepe het dit ook duidelik na vore gekom dat die teaterproduksie alternatiewe tot verwerping daargestel het. Hieroor sê Combrink (2002:3) "...we use drama and music as a transformation process...to act out alternative possibilities in their lives."

Vervolgens word die groei en persepsieverandering wat plaasgevind het met betrekking tot aanvaarding van ander, selfaanvaarding en aanvaarding van omstandighede afsonderlik hanteer. 


\section{Aanvaarding van ander}

Temas wat tydens die data-insamelingsprosesse voor en na die produksie na vore gekom het, was aanvaarding van ander op grond van hulle menswees en ten spyte van hulle $\mathrm{ras} / \mathrm{kultuur} / \mathrm{taal}$, ander se menings en hulle ekonomiese stand; nie-veroordelende aanvaarding, deur ander te aanvaar op grond van hulle innerlike skoonheid en ten spyte van uiterlike voorkoms. Aanvaarding is ook in verband gebring met liefde, vriendskap en respek. Aanvaarding deur ander word as voorwaarde gestel vir aanvaarding van die self.

Bykomende temas wat na afloop van die teaterproduksie na vore gekom het, word vervolgens voorgehou. Die feit dat hierdie temas slegs na afloop van die produksie in die fokusgroepe na vore gekom het, dui daarop dat groei en persepsieverandering met betrekking tot aanvaarding beslis plaasgevind het weens die produksie. Aanvaarding is in verband gebring met sukses en 'n persoon se vermoë om te kan gee. Jaloesie is as teenoorgestelde van aanvaarding voorgehou. Die feit dat die deelnemers se familielede by die produksie was en hulle ondersteun het, was vir die deelnemers 'n aanduiding van aanvaarding. Ander (nie-deelnemers) se persepsie teenoor die deelnemers het verander en ook dít was vir hulle 'n aanduiding van aanvaarding. Aanvaarding van die deelnemers deur die produksiespan en ook van mekaar onderling het sterk na vore gekom.

\section{Selfaanvaarding}

Die enigste tema wat beide voor en na die teaterproduksie uitgestaan het, was selfaanvaarding ten spyte van ander se menings. Temas wat slegs tydens die fokusgroepe na afloop van die teaterproduksie na vore gekom het en dus op groei en persepsieverandering dui, was eerstens dat selfaanvaarding ten spyte van probleme 'n verantwoordelikheidsin kan meebring, en tweedens dat selfaanvaarding verband hou met selfvertroue. 'n Tema wat deurlopend aandag geniet het, was dat wanneer 'n persoon hom met ander vergelyk en deurentyd begeer om soos die ander te wees, hy blykbaar homself nie aanvaar nie.

\section{Aanvaarding van omstandighede}

Temas wat voor en na die teaterproduksie aandag geniet het, was aanvaarding van besittings en aanvaarding van die verlede of van verlies. Temas wat slegs na die produksie in die fokusgroepe na vore gekom het, was dat iemand soms wens dat hy/sy in iemand anders se omstandighede kon verkeer omdat die aanname gemaak word dat dit beter sou wees; dat omstandighede aanvaar kan word ten spyte van probleme (byvoorbeeld alkoholisme, verwerping deur ' $\mathrm{n}$ biologiese ouer of 'n stiefouer) aangesien ander mense in ander omstandighede ook probleme ondervind; en dat empatie bewerkstellig word wanneer 'n persoon hom in 'n ander een se situasie/omstandighede kan indink.

Die feit dat daar ander temas na afloop van die teaterproduksie na vore gekom het, dui op persepsieverandering wat plaasgevind het rakende die begrip aanvaarding. Die deelnemers het dikwels na hulle eie omstandighede of ervaringe by die skool of tuis verwys wanneer hulle vertel het wat hulle ten opsigte van aanvaarding geleer het. Hieruit is dit duidelik dat die deelnemers persoonlike groei ondergaan het.. Die teaterproduksie het geleentheid geskep vir aanvaarding om plaas te vind, en dat die deelnemers dit kon identifiseer, internaliseer en toepas.

\section{AANBEVELINGS}

Uit die temas wat uit die bevindinge voortgespruit het, word die volgende aanbevelings aan die hand gedoen: 
- Die produksiespan wat tydens die aanleer van 'n teaterproduksie met adolessente werk, moet uiters geduldig en nie-veroordelend wees en 'n passie hê om met die spesifieke teikengroep te werk.

- Dit is voordelig dat 'n teks spesifiek vir die teikengroep waarmee daar gewerk word, geskryf moet word met die inagneming van die tema, taal, kultuur, ouderdom, belangstellings, milieu en sosio-ekonomiese problematiek van die teikengroep en die tipe gehoor.

- Die behandeling van die tema van 'n teaterproduksie voordat daar met die instudering daarvan begin word, word sterk aanbeveel, aangesien dit die ervaringsleerproses versterk.

- Verdere navorsing kan fokus op spesifieke temas vir gemeenskapsteater-produksies.

- Daar moet genoeg tyd afgestaan word aan die vervaardiging van die produksie sodat die tema geïnternaliseer kan word.

\section{SAMEVATTING}

Die invloed van deelname aan 'n teaterproduksie op adolessente in Promosa se persepsie en persoonlike groei ten opsigte van aanvaarding is in hierdie artikel bespreek. Teater as vorm van gemeenskapsontwikkeling en -opvoeding kan besonder geslaagd aangewend word vir die oordrag en internalisering van waardes, kennis en vaardighede, veral onder adolessente. Die feit dat die teaterproduksie As die skoen jou pas ... spesifiek geskryf is om die problematiek rakende aanvaarding onder adolessente in Promosa onder die loep te neem het die effektiwiteit van hierdie projek verhoog. Daar is bevind dat die deelnemers se persepsie ten opsigte van aanvaarding verbreed en verander het, en dat persoonlike groei tydens die verloop van die Karos \& Kambro-proses plaasgevind het.

\section{BIBLIOGRAFIE}

ARTSLYNX INTERNATIONAL ARTS RESOURCES. 2004. Arts Empowerment. [Web:] http://www.artslynx.org/heal/about.htm [Datum van gebruik: 14/05/2007].

COMBRINK, A. 2007. As die skoen jou pas. Pretoria: Karos \& Kambro.

COMBRINK, S. 2002. Karos \& Kambro: Building the future of South Africa. Pretoria: Karos \& Kambro.

COMING UP TALLER. 2006. Social and emotional development. [Web:] Error! Hyperlink reference not valid. [Datum van gebruik: 14/05/2007].

COMING UP TALLER. 2006. Learning and academic performance. [Web:] Error! Hyperlink reference not valid. [Datum van gebruik: 14 Mei 2007].

DRYDEN, W. 1998. Developing self-acceptance: a brief, educational, small group approach. Chichester: John Wiley \& Sons.

FOUCHÉ, C.B. 2005. Qualitative research designs. In: DE VOS, A.S., STRYDOM, H., FOUCHÉ, C.B. \& DELPORT, C.S.L. Research at grass roots: for the social sciences and human service professions. Pretoria: Van Schaik Publishers: 267-273.

HAT (VERKLARENDE HANDWOORDEBOEK VAN DIE AFRIKAANSE TAAL). 1994. Doornfontein: Perskor.

JANSEN VAN RENSBURG, N.S. 1985. Die belewing van etniese grense in Promosa, Potchefstroom. Potchefstroom: PU vir CHO. 
LIESBLICH, A. \& JOSSELSON, R. 1997. The narrative study of lives. USA: Sage Publications.

LOUW, D.A., VAN EDE, D.M. \& LOUW. A.E. 2004. Menslike ontwikkeling (6e uitg). Kaapstad: CTP-Boekdrukkers.

NAUDÉ, W.A. 2004. Potchefstroom Socio-Economic Survey. Potchefstroom: PU vir CHO.

OSTIGUY, L., HOPP, R. \& SWEDBURG, R. 1995. Partners in programming: Concordia University Inner City Project. Alternatives to incarceration: Prevention or treatment. Monograph on youth in the 1990s. 4:1-13. Feb. (Opsomming in die ERIC databasis, verwysingsnommer: ED384466)

OXFORD DICTIONARY OF ENGLISH. 2003. Oxford, N.Y.: Oxford University Press.

STATISTICS FOR POTCHEFSTROOM MUNICIPALITY - WARD 9. 2005. [Web:] http://www.statssa.gov.za/ [Datum van gebruik: 01/05/2007]

STRYDOM, H. 2005. Ethical aspects of research in the social sciences and human service professions. In: DE VOS, A.S., STRYDOM, H., FOUCHÉ, C.B. \& DELPORT, C.S.L. Research at grass roots: for the social sciences and human service professions. Pretoria: Van Schaik Publishers: 56-70.

VAKTAALKOMITEE VIR MAATSKAPLIKE WERK. 1996. Nuwe woordeboek vir Maatskaplike Werk (hersiene en uitgebreide uitgawe). Parow: CTP Book Printers (Pty) Ltd.

VINES, G. 2005. Middle schooling counseling: touching the souls of adolescents. Professional School Counseling, 9(2):175-176. Opsomming in die PsycINFO databasis, verwysingsnommer: 2005-16254-015)

WEYERS, M.L. 2001. The theory and practice of community work: a South African perspective. Potchefstroom: Keurkopie.

Me Madeleen Combrink, student (2008); Prof Herman Strydom; Dr Wilhelm van Deventer, Vakgroep Maatskaplike Werk, Skool vir Psigo-sosiale Gedragswetenskappe, Noordwes-Universiteit (Potchefstroomkampus), Potchefstroom, Suid-Afrika. 